\title{
Anaphylactic Reaction to Pemetrexed: A Case Report
}

Héloise Capelle ${ }^{1}$, Joelle Birnbaum ${ }^{2}$, Pascale Tomasini ${ }^{3}$, Céline Tummino ${ }^{2}$, Marion Gouitaa ${ }^{2}$, Nathalie Ausias ${ }^{1}$, Denis Charpin $^{2}$, Fabrice Barlesi ${ }^{3}$, Marc Montana ${ }^{1-4}$

${ }^{1}$ Oncopharma, Hôpital Nord, AP-HM, Marseille, France. ${ }^{2}$ Service de Pneumologie, Hôpital Nord, AP-HM, Marseille, France. ${ }^{3}$ Oncologie multidisciplinaire et innovations thérapeutiques, Hôpital Nord, AP-HM, Marseille, France. ${ }^{4}$ AixMarseille Université, CNRS, Institut de Chimie Radicalaire ICR, UMR 7273, Laboratoire de Pharmaco-Chimie Radicalaire, Marseille, France.

Received, February 7, 2014; Revised, April 10, 2014; Accepted, May 16, 2014; Published, May 17, 2014.

ABSTRACT - Pemetrexed is approved to treat non-small cell lung cancer and has an overall favorable toxicity profile. We describe a 58-year-old man who developped an anaphylactic shock within few minutes from the beginning of pemetrexed perfusion. Pemetrexed was discontinued and the patient's symptoms gradually resolved with administration of symptomatic treatment. Serum tryptase level remained normal and intra dermal skin tests were negative eventhough a nonspecific papule was noted. This case suggests that caution should be exercised when prescribing pemetrexed and clinicians must be warranted for the possibility of serious adverse events associated with pemetrexed use.

This article is open to POST-PUBLICATION REVIEW. Registered readers (see "For Readers") may comment by clicking on ABSTRACT on the issue's contents page.

\section{INTRODUCTION}

Pemetrexed is a multitargeted antifolate approved for the treatment of malignant pleural mesothelioma and non-small cell lung cancer. Although this molecule is generally well tolerated, a dose-dependant hematologic toxicity is its most common side effect. Skin toxicities are another well-recognized side effect of pemetrexed but severe skin reactions after pemetrexed administration are rare $(1,2)$. We report a case of a man who developed an anaphylactic reaction within few minutes from the beginning of pemetrexed perfusion.

\section{OBSERVATION}

A 58-year-old man was treated in 2008 for a primary lung adenocarcinoma with surgical resection and radiation treatment plus 4 cycles of platinum-based chemotherapy (cisplatin / docetaxel). To treat lung adenocarcinoma recurrence, he was hospitalized in March 2011 for the administration of the first course of chemotherapy with pemetrexed $500 \mathrm{mg} / \mathrm{m}^{2}$ and cisplatin $75 \mathrm{mg} / \mathrm{m}^{2}$ every three weeks. The Eastern Cooperative Oncology Group (ECOG) performance status was 0 . Pulmonary auscultation brought out no significant abnormality and complete blood count was included in normal range with white blood cells $5 \mathrm{G} / \mathrm{L}$, red blood cells $4.41 \mathrm{G} / \mathrm{L}$, hemoglobin $127 \mathrm{~g} / \mathrm{L}$ and platelets $218 \mathrm{G} / \mathrm{L}$.
The first day of chemotherapy, aprepitant (125 mg, po), ondansetron (8 mg, IV), methylprednisolone $(120 \mathrm{mg}, \quad \mathrm{IV}), \quad$ and pantoprazole $(40 \mathrm{mg}$, IV), were respectively administered to the patient, $1 \mathrm{~h}, 30$ minutes, 20 minutes and 10 minutes before the pemetrexed infusion. Within 5 minutes from the beginning of pemetrexed, the patient suddenly developed hypotension $(4 / 2 \mathrm{~mm} \mathrm{Hg})$, undetectable pulse in periphery, $\mathrm{O}_{2}$ saturation inferior to $60 \%$ on room air, and, in a second time, urticaria and loss of consciousness.

The chemotherapy was stopped and dexchlorpheniramine $(10 \mathrm{mg}$, IV) followed by methylprednisolone $(2 \mathrm{mg} / \mathrm{kg}, \quad$ IV $)$ and hydroxyethyl starch $(500 \mathrm{ml}, \mathrm{IV})$ were prescribed to the patient. The patient regained a normal blood pressure $(11 / 7 \mathrm{~mm} \mathrm{Hg})$ without the use of adrenaline. Aerosols of terbutaline and ipratropium bromide were injected to treat bronchospasm. The symptoms gradually resolved and regression of urticaria was observed with the use of corticosteroids $(1 \mathrm{mg} / \mathrm{kg})$, dexchlorpheniramine and desloratadine $(5 \mathrm{mg}$, po daily).

A few minutes after the beginning of symptoms, a blood sample was collected for the serum tryptase level $(\mathrm{STL})(\mathrm{STL}=8.52 \mu \mathrm{g} / \mathrm{L}$; STL normal range $<11 \mu \mathrm{g} / \mathrm{L}$ ).

\footnotetext{
Corresponding Author: Marc Montana, UFR Pharmacie, Laboratoire de Chimie Thérapeutique, 25 bd Jean Moulin, 13005 Marseille, France ; Email: marc.montana@univamu.fr
} 
In order to determine the origin of this event, skin allergy tests were conducted. Intra dermal skin tests were negative to pemetrexed, ondansetron and pantoprazole (dilutions used: $1 / 10,000 ; 1 / 1,000 ; 1 / 100$ et $1 / 10)$. However, the presence of a mild local reaction to pemetrexed was noted. Basophil activation tests were negative in vitro in the presence of ondansetron and pantoprazole.

\section{DISCUSSION}

Anaphylaxis is a severe, potentially fatal, systemic allergic reaction that suddenly occurs after contact with an allergy-causing substance. In this case report, anaphylaxis was attributed to pemetrexed. Ondansetron and pantoprazole were also suspected. Indeed, anaphylactoid reactions have already been reported in patients receiving these drugs (3-4). However, ondansetron was previously used as premedication for this patient and skin allergy tests for these two drugs were negative. Proton-pump inhibitors were readministered to the patient without any problem.

This is the second report of anaplylaxis from pemetrexed (5). Even though STL may support the diagnosis of anaphylaxis, normal levels do not rule it out (5-6). Moreover, tryptase was probably collected too early and the kinetic of elevation of this enzyme is lacking. In the second hand, to the best of our knowledge, it is the first description of pemetrexed intradermal skin testing. The advantage of these tests, well documented for other anticancer drugs such as platinum salts, remains unclear for pemetrexed.

\section{CONCLUSION}

Pemetrexed has demonstrated efficacy in the treatment of lung cancer through its antimetabolic action as an analogue of folic acid. It is a cytotoxic drug relatively well tolerated compared to cytotoxic treatment in general. Because of the risk of anaphylactic reaction, we recommend that patients should be monitored closely and clinicians must be warranted for the possibility of serious adverse events associated with pemetrexed use.

\section{REFERENCES}

1. Tummino C, Barlesi F, Tchouhadjian C, Tasei AM, Gaudy-Marqueste C, Richard MA, Astoul P. Severe cutaneous toxicity after Pemetrexed as second line treatment for a refractory non small cell lung cancer Rev Mal Respir, 2007; 24(5):635638.

2. Lopes G, Vincek V, Raez LE. Pemetrexedassociated urticarial vasculitis. Lung Cancer, 2006; 51:247-249.

3. Kepil Özdemir S, Yılmaz I, Aydin Ö, Büyüköztürk $\mathrm{S}$, Gelincik $\mathrm{A}$, Demirtürk $\mathrm{M}$, Erdoğdu D, Cömert S, Erdoğan T, Karakaya G, Kalyoncu AF, Oner Erkekol F, Dursun AB, Misirligil Z, Bavbek S. Immediate-type hypersensitivity reactions to proton pump inhibitors: usefulness of skin tests in the diagnosis and assessment of cross-reactivity. Allergy, 2013; 68(8):1008-1014.

4. Fernando SL, Broadfoot AJ. Ondansetron anaphylaxis: a case report and protocol for skin testing. Br J Anaesth, 2009; 102(2):285-286.

5. Kumar Shah B, Hewett Y. Pemetrexed-induced anaphylaxis. Acta Oncol, 2013; 52(4):881.

6. Simons FE, Frew AJ, Ansotegui IJ, Bochner BS, Golden DB, Finkelman FD, Leung DY, Lotvall J, Marone G, Metcalfe DD, Müller U, Rosenwasser LJ, Sampson HA, Schwartz LB, van Hage M, Walls AF. Risk assessment in anaphylaxis: current and future approaches. J Allergy Clin Immunol, 2007; 120:S2. 